\title{
Proliferative activity and motoneurone recruitment persist at the spinal cord central canal during larval and some postlarval stages in the rainbow trout (Oncorhynchus mykiss)
}

\author{
A. Alunni', F. Pierucci', M. Aita' ${ }^{2}$ V. Margotta ${ }^{1}$, R. De Vita ${ }^{3}$, and L. Alfei ${ }^{1}$
}

'Department of Animal and Human Biology of the University of Rome "La Sapienza", via Alfonso Borelli, 5000161 Rome, Italy; ${ }^{2}$ Department of Physiology of The University of Rome "La Sapienza", P.le Aldo Moro, 5, 00185, Rome, Italy and ${ }^{3}$ Environmental Epidemiologic Unit, ENEA Casaccia, Via Anguillarese 301, 00060 Rome, Italy

Accepted: 5/2/01

Key words: PCNA, immunohistochemistry, cervical and caudal spinal cord, morphometry, neurogenesis, regeneration

\section{SUMMARY}

We previously found a linear relationship between the cross sectional myotomal area and the motoneurone number in the growing trout during postlarval stages. These neurones increased in number until a fish length of $150 \mathrm{~mm}$, which prompted us to examine how motor neurones are recruited afterwards to meet the growth of their target myotomal muscle.

Young adult (260 $\mathrm{mm}$ in length), fingerlings ( $\mathrm{F}$, $120-170 \mathrm{~mm})$, fry $(\mathrm{Fr}, 70 \mathrm{~mm})$ and eleutherembryos (Es, 20-30 mm) of rainbow trout (Oncorhyncus mykiss) were employed in this study. PCNA immunohistochemistry was used for monitoring the proliferative activity in the epithelium of the spinal cord central canal. This activity was quantified as the number of PCNA labelled cells for each spinal cord section. In Es and Fry, a mean value of 3-5 labelled cells for each section was found with a sharp decrease in young F (120 mm long). After this fish length, it was not possible to quantitatively evaluate the proliferative activity at the central canal. However, labelled cells were seldom found in the spinal cord sections until a fish length of 260 $\mathrm{mm}$. From these data it is possible to conclude that motoneurone recruitment in the trout spinal cord is down-regulated at the F stage. Afterwards, we found that motoneurones increase in size to meet the growth of their target myotomal muscle.

\section{INTRODUCTION}

Adult brain structures in the trout are well characterized (Nieuwenhuys et al., 1998), but large gaps in this knowledge exist regarding trout brain morphogenesis during postembryonic through to adult stages. Proliferation is a central dynamic feature of the developing brain and its developmental regulation stands at the foundations of building a particular brain phenotype. Comparative research on adult brain has led to the conclusion that there is a basic neural proliferation pattern common to all vertebrates, including teleost fishes (Northcutt 1995; Wullimann et al., 1996; Nieuwenhuys et al., 1998; Wullimann 1997) and deviations from these common patterns of proliferation can be recognized and related to the generation of specific brain phenotypes. 
In all mammalian species examined so far, postnatal neurogenesis is either completely absent (Rakic, 1985) or is observed in only very few brain regions, with the number of newly born cells being extremely low (Altman, 1962, 1963, 1969a, b; Altman et al., 1965; Mares et al.,1974; Bayer at al.,1982; Kaplan et al., 1983; Corotto et al., 1993; Lois et al., 1993, 1994; Gould et al., 1998). As a consequence, replacement of neurones lost as a result of neurodegenerative disease or injuries is usually impossible in the adult mammalian brain. These limitations contrast with the enormous potential of teleost fish for neurogenesis and gliogenesis during adulthood. Earlier studies in these vertebrates indicated that the capability to produce new neurones and glial cells, as well as the ability to regenerate neural tissue after injuries, is very pronounced and, in at least a few brain regions, persists over long periods of life (Johns, 1977; Meyer, 1978). This proliferative capacity parallels the enormous ability of fish to regenerate axons and even whole neurones in the central nervous system after injuries or experimentally induced lesions (Meyer et al., 1985; Waxman et al., 1986; Stuermer et al., 1992).

Previous papers have established evidence for the continuous production of nerve cells in various areas of the teleost brain beyond the embryonic stages of development (Zupanc, 1999 for review; Wullimann et al., 1999; Van Nguyen et al., 1999) using BrdU or PCNA (proliferating cell nuclear antigen) immunohistochemistry to label proliferating cells. However, no data have yet been reported for the fish spinal cord. We started, therefore, to examine postembryonic neurogenesis in the rainbow trout (Oncorhynchus mykiss) spinal cord. Trout belong to a continuously growing species of fish, in which the formation of new muscle fibres continues well into adult life (Koumans et al., 1995). We consequently supposed that the increase in the number of peripheral motor elements are supported by a concomitant increase in the number of central neuronal elements involved in the physiological control of the associated muscle activity with a continuous recruitment of new nerve cells. In a previous paper (Alfei et al., 1984) we reported an increase in the number of spinal motoneurones in the trout and related this to the growing axial muscle size.

\section{MATERIALS AND METHODS}

\section{Animals}

Rainbow trout (Oncorhynchus mykiss) were supplied by a local fish farm (ARSIAL, Regione Lazio, Rome). Young adult (260 $\mathrm{mm}$ in length), fingerlings ( $\mathrm{F}, 120-170 \mathrm{~mm}$ in length), fry ( Fr, 70 $\mathrm{mm}$ in length) and eleutherembryos (Es, 20-30 $\mathrm{mm}$ in length) of rainbow trout were employed in this study. Three or more animals were examined from each of these stages. Fish were collected over a two year period (Jan 1997-Jan 1999) at one month intervals. The experiments were performed as soon as the animals arrived in the laboratory in agreement with the European Union regulation concerning the protection of experimental animals. Animals were deeply anaesthetized with $0.1 \%$ tricaine methane sulfonate (MS222, Sigma, St. Louis, USA) and fixed either by transcardial perfusion [teleost Ringer's solution followed by $4 \%$ paraformaldehyde in $0.1 \mathrm{M}$ phosphate buffer, (PB), $\mathrm{pH}$ 7.4] or by immersion in Bouin fluid (fry and eleutherembryonic stages). Spinal cords from perfused animals were dissected out under the stereomicroscope and left in cold fixative for three more hours.

Whole specimens (Es and Fr) and dissected spinal cords were then processed to perform histological and immunohistochemical techniques. After fixation, trout specimens were dehydrated and embedded in paraffin before they were cut transversely on a rotary microtome at $8 \mu \mathrm{m}$. Sections were mounted bi-serially on glass slides covered with poly-L-lysine (Sigma-Aldrich, Milan, Italy). One series of slides from each trout stage were stained with haematoxylin eosin (H.E.) before they were dehydrated and coverslipped with Entellan (Merck, Darmstadt, Germany).

\section{PCNA Immunohistochemistry}

Deparaffinized and rehydrated mounted sections were washed in $\mathrm{PB}, \mathrm{pH} 7.2$ and treated sequentially in a solution of $3 \% \mathrm{H}_{2} \mathrm{O}_{2}$ in methanol for 15 minutes to inactivate endogenous peroxidases; in Triton $0.3 \%$ in $\mathrm{PB}$ for $5 \mathrm{~min}$, and in normal horse serum, NHS, 20\% in PB, for 1 hour. The sections were then incubated with the primary antibody (anti PCNA, PC10 moAb mouse IgG Sigma, n. P-8825 (1:1000 dilution in $1 \%$ NHS in PB) overnight at $4^{\circ} \mathrm{C}$. After washing three times in PB with $1 \%$ NHS, the sec- 
tions were incubated with biotinylated horse-antimouse secondary antibody (1:100 in PB/1\% NHS Vector Laboratories, Burlingame Calif. USA) for 1hour at room temperature (r. t.), followed by $1.8 \%$ avidin bound peroxidase complex (ABC-kit, Vector), 30 minutes. After washing twice in Tris- $\mathrm{HCl}$ buffer, pH 7.6 (5 minutes each), the sections were processed for visualization of peroxidase activity by using $0.05 \%$ 3-3'diaminobenzidine tetrahydrochloride $(\mathrm{DAB})$ with $1 \%$ nickel-sulfate and $0.01 \%$ hydrogen peroxide in $0.05 \% \mathrm{M}$ Tris- $\mathrm{HCl}$ buffer (Sigma-Aldrich). Slides were then dehydrated and coverslipped using Entellan (Merck, Germany)

The specificity of the immunostaining was tested in all cases by replacement of the primary antiserum with immune horse serum alone. These control experiments completely abolished the immunoreaction in all spinal cord regions. Sections were viewed on a Leitz Laborlux microscope (Leica AG, Heerbrugg, Switzerland) and photographed.

\section{Quantitative analysis}

At adult and F stages, dissected spinal cords were cut into $10 \mathrm{~mm}$ pieces at cervical and caudal levels. Cervical level was located behind the pectoral fin corresponding to the sixth vertebra and ventral motor roots 6-7; caudal level was located in the middle of the tail peduncle (ventral roots 45-46). Cross sections of the whole fish at these levels, stained with H.E., were used for measuring the myotomal area. Eight contiguous sections were analysed in each level as a function of the fish length by means of an image analyzer (Quantimet, Leica) (Fig. 1A).

In whole specimens, the length of cervical and caudal spinal cords was obtained by dividing the length of the entire spinal cord by three. In all the specimens, PCNA labelled cells at cervical and caudal levels were counted in all the spinal cord sections contained in the corresponding area. In each spinal cord section, PCNA labelled cells in the central canal epithelium (EC) were counted (Fig. 1B). The number of PCNA labelled cells for each section was estimated by dividing the total number of labelled cells by the number of sections contained in $10 \mathrm{~mm}$ of cervical and caudal spinal cord (adult and F) or in the estimated third of the spinal cord length (other stages). Data were statistically evaluated and expressed as means with their standard errors (SD). Student's t-test statistics were used to evaluate the individual variability within each growth class.

\section{RESULTS}

Myotomal area at the two examined levels, cervical and caudal, gradually increased at Es (20-30 $\mathrm{mm})$ and $\mathrm{Fr}(70 \mathrm{~mm})$ stages with a sharp increment after the $F(120 \mathrm{~mm})$ stage (Fig.1A). Myotomal areas of smaller size were always observed at caudal level (Fig. 1A).

Using H. E. staining, it was possible to observe the morphology of the central canal and of the spinal motoneurones (Fig. 2). In $20 \mathrm{~mm}$ long Es, many mitoses were seen in the epithelium lining the central canal but only few differentiated motoneurones were observed. During the next stages, the number of differentiated motoneurones increased (Fig. 2, B, C). Numerous principal (P) and secondary $(\mathrm{S})$ motoneurones were seen in each spinal cord section at cervical and caudal level. However, after the fish length of $120 \mathrm{~mm}$, the motoneurone number for each section decreased but their size was much larger (Fig . 2 D, E, F) .

During larval stages (Es, fry and $120 \mathrm{~mm}$ long F), many PCNA labelled cells were seen in each section of the cervical (Fig. 3) and caudal spinal cord (Fig. 4) in the epithelium lining the central canal and as migrating cells in the dorsal, lateral and ventral funiculi. The mean values of labelled cells for each section in the epithelium of the central canal were significantly higher at early larval stages $(30 \mathrm{~mm}-60 \mathrm{~mm})$ and at cervical level where a mean of 3,5 labelled cells for each section was found (Fig. 1B). At caudal level, a lower amount of proliferating cells for each section was always found (Fig. 1B). At these stages, it was possible to observe with high reproducibility a maximum of labelling in the middle of each spinal segment (data not shown). Numerous labelled nuclei were also seen at the level of the myotomal muscle (Fig. 5A, B).

After the fish length of $120 \mathrm{~mm}$, in coincidence with a sharp myotomal area increase, and until the adult stage of $260 \mathrm{~mm}$, the labelling at the central canal was still present at the two levels considered but always with very low values and not in every section, which made it difficult to quantify (Fig. 3, 


\section{Myotomal area}

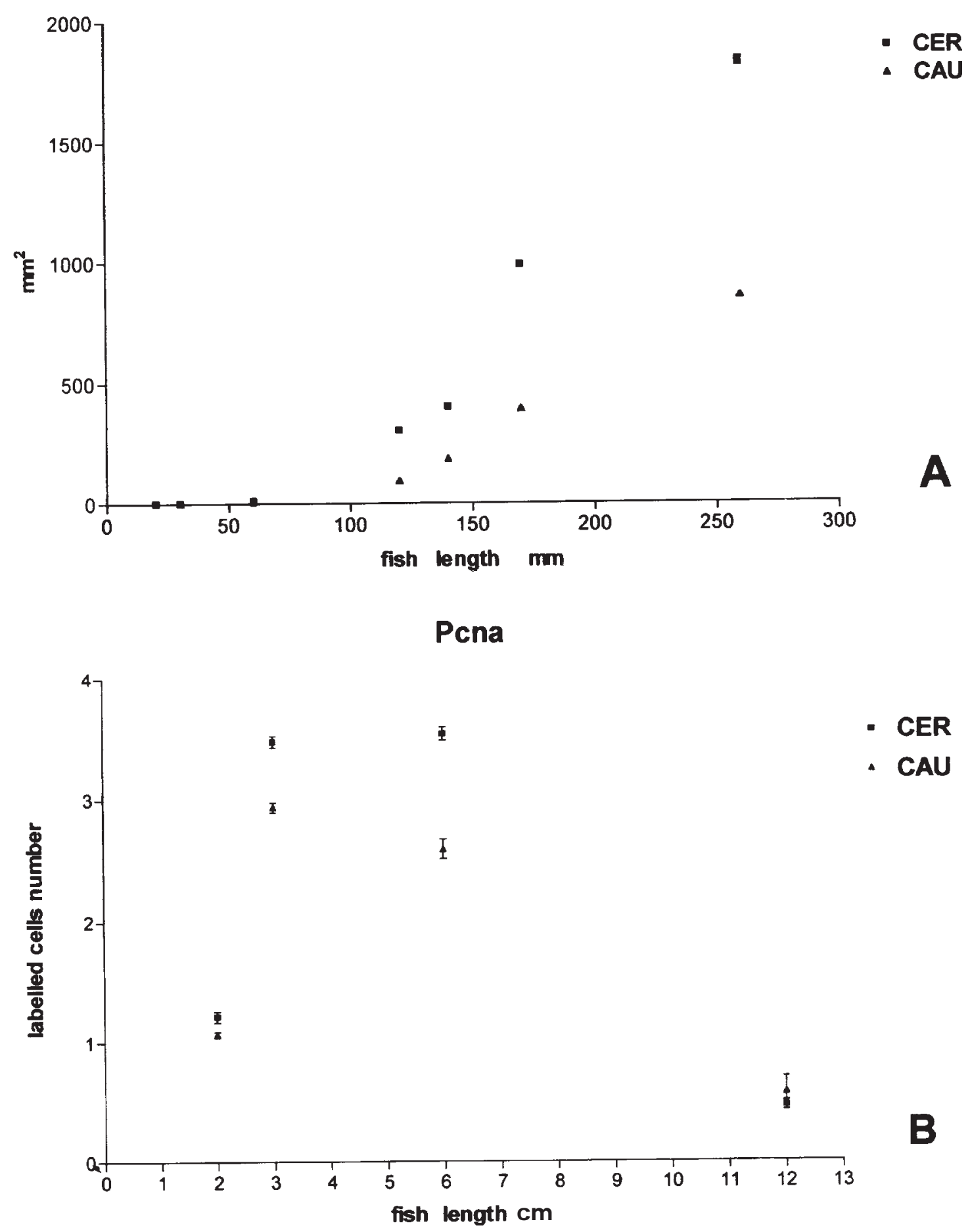

Fig. 1 - A) Myotomal area size as a function of trout (Oncorhynchus mykiss) length; B) PCNA labelled cells in the epithelium lining the spinal cord central canal (mean values $\pm \mathrm{SD}$ ) as a function of the fish length. 
4). On the contrary, at these stages, many proliferation zones were seen in the brain, at ventricular and peri-ventricular locations (in preparation).

\section{DISCUSSION}

\section{PCNA immunohistochemistry}

The cytological presence of PCNA is considered a reliable marker of proliferative activity in normal and pathological tissues (Bravo et al., 1981; Fairman et al., 1990; Yu et al., 1992; Casasco et al., 1993); it functions as a co-factor of DNA polymerase $\delta$ and is necessary for DNA replication and repair in proliferating eukaryotic cells (Jaskulski et al., 1988; Liu et al., 1989; Baserga, 1991; Chen et al., 1996).

In recent years, PCNA immunohistochemistry in fish tissues has been widely used for monitoring, for example, proliferating cells in goldfish retina (Negishi et al., 1990; 1991), proliferating myosatellite cells during myotomal muscle growth of carp (Alfei et al., 1994) and postembryonic neural proliferation in the zebrafish forebrain (Wullimann et al., 1999). However, with this method, the nucleoplasmic PCNA fraction (Bravo et al., 1987) remains detectable also in the other phases of the cell cycle after formaldehyde-based fixation, as used in our study. This fraction increases through G1, peaks at the G1/S interface and decreases through G2 (Morris et al., 1989). In longer-term quiescent cells, PCNA is below the detection level (Bravo et al., 1987; Yu et al., 1992). This is apparent in immunohistochemical investigations using the PC10 antibody in various normal tissues, where labelled cells are only present in the germinal centers (Waseem et al., 1990; Yu et al., 1992; Casasco et al., 1993).

The expression of PCNA has recently been studied in the brain of adult and developing mice by Ino et al. (2000). They found that in the cortical neuroepithelium of developing mice the immunoreactivity of PCNA was more widely distributed than that of the more specific 19F4 antibody and PCNA mRNA expression. According to these authors, the PCNA protein recognized in neurons only with PC10 antibody may be a modified form, most probably a phosphorylated PCNA.

Thus, in this paper we cannot make any statement about proliferative cells in the S-phase, but only about growing cells with a proliferative potential (cycling cells) as opposed to quiescent cells. Furthermore, we must consider a possible overestimation of cycling cells on the basis of the paper by Ino et al. (2000). However, with PC10 immunohistochemistry we obtained lower values for proliferating cells than we expected. These results, and the specificity of cell locations, should be appropriate for showing proliferation zones in the developing fish spinal cord.

\section{Proliferation in the spinal cord}

Few papers exist on the distribution of postnatal proliferation zones in the brain of adult fish (see Zupanc, 1999, for review), while no data exist so far for the fish spinal cord.

In the present study we have found that a recruitment of new cells from the central canal, formerly acting as a germinal zone from which neuroblasts and glioblasts are originated during embryonic stages, occurs in the trout spinal cord at all the stages considered. The proliferative activity at the caudal level was found to be lower, probably in relation to the smaller size of this body section. However, the proliferative rate at the cervical and caudal levels becames very low after a fish length of $120 \mathrm{~mm}$.

In an earlier paper we analyzed the relationship of the spinal motor pool to its target muscle during post-larval growth in the trout (Alfei et al. , 1989) which we demonstrated to be linear. This is possible because of the segmental organization of fish spinal cord (Westerfield et al., 1986) by which each motoneurone possesses a single axon that exits via a single ventral root. Furthermore, spinal segments appear to correspond with muscle segments. Myotomal muscle growth proceeds by two mechanisms: hyperplasia, by which numerous new fibres are added; and hypertophy, by which existing fibres increase in size. These myotomal muscle growth phases have been recorded for rainbow trout (Oncorhyncus mykiss) where hyperplasia is the main growth process up to $200 \mathrm{~mm}$, and hypertrophy assumes increasing importance until it becomes the only growth process at approx. $60 \mathrm{~cm}$ (Weatherley et al., 1980; Stickland, 1983; Weatherley et al., 1989). As a result of this long lasting recruitment of new fibres due to the hyperplastic modality of myotomal muscle growth in the post-larval fish, we expected to see the persistence of high proliferative activity in the epithelium of the spinal cord central 

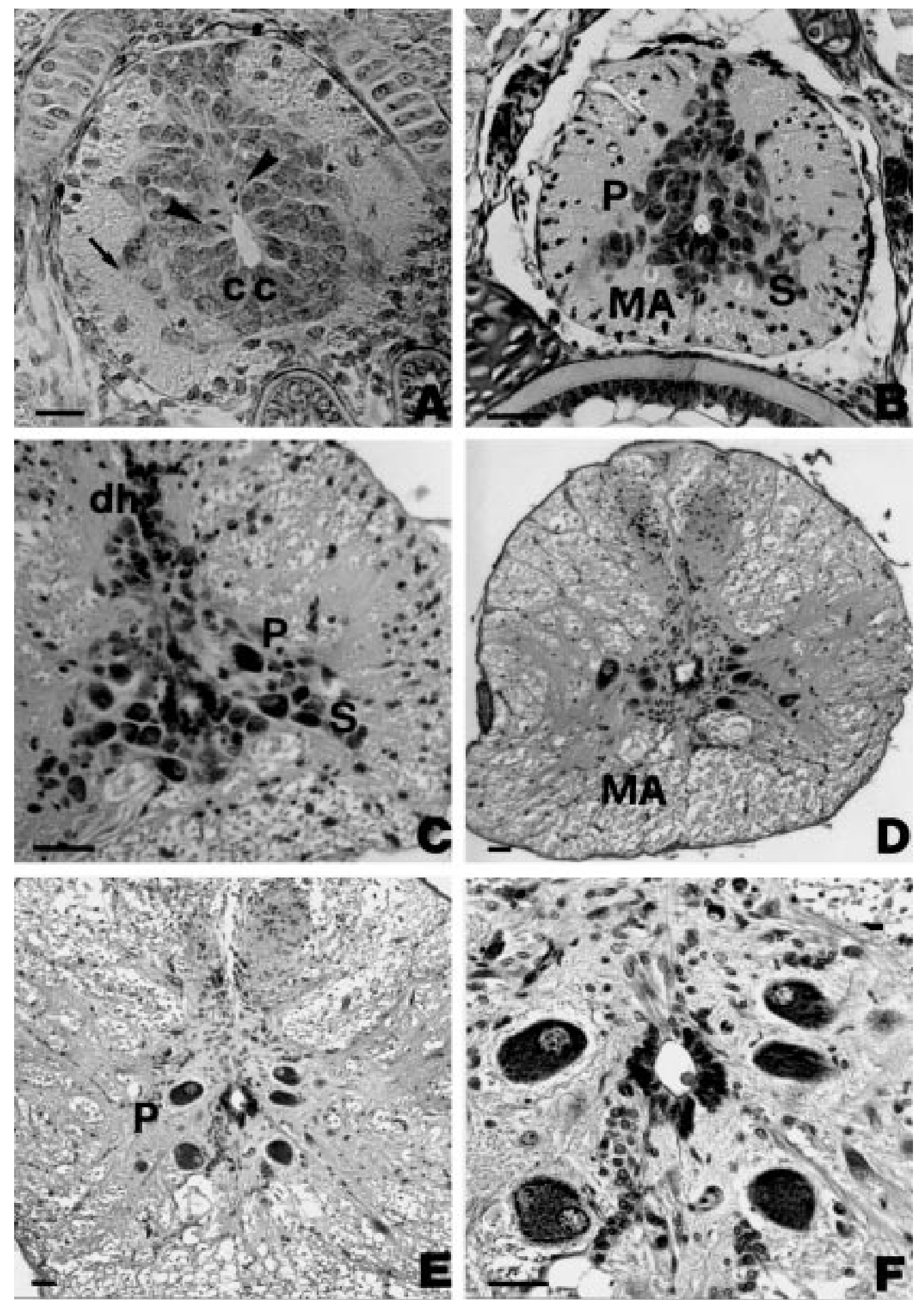
canal for supporting the continuous recruitment of new motoneurones. Indeed, a linear relationship between $\mathrm{P}$ motoneurone number and myotomal area had already been demonstrated by us for trout lengths up to150 $\mathrm{mm}$ (Alfei et al., 1989).

On the contrary, after the fish length of $120 \mathrm{~mm}$, we found, in spite of the large increase of myotomal area, not only a very low proliferative activity at the central canal but also a decreased number of motoneurones for each spinal cord section. However, the motoneurone size was much larger.

On the basis of these results it may be proposed that motoneurone recruitment is down-regulated around this fish length. So to face the enlarging myotomal muscle target at this age, motoneurone growth might be produced by hypertrophy rather than by recruitment of new neurones. Actually, a large increase in the $\mathrm{P}$ motoneurone area has been previously noticed by us in F trouts (Alfei et al., 1989). The young F stage might therefore be considered as a crucial stage in trout spinal cord development.

These data for the trout are of particular interest if we consider the high potential for spontaneous regeneration present in fish transected spinal cord (Coggeshall et al., 1983; Prasada Rao et al., 1987; 1993; Sharma et al., 1993). Some considerations would argue against the contribution of newly born cells to the reestablished projections in lesioned adult zebrafish spinal cord (Becker et al., 1997). Regeneration of transected axons in fish has been recognized as not depending on a new neurogenesis process but only on axonal regrowth of severed axons (Becker et al., 1997). These data support our findings in the trout that neurogenesis is down-regulated in the spinal cord at F stage. In addition, no evidence for pronounced neurogenesis in the adult fish brainstem (Zupanc et al., 1995) or spinal projecting brain nuclei (Bosch et al., 1994) has been reported so far.

\section{ACKNOWLEDGEMENTS}

This research was supported by a grant from the Italian Ministry of the University and Scientific and Technological Research to L.A. The authors wish to thank Dr. E. Gelosi (ARSIAL.) for providing rearing fish facilities.

\section{REFERENCES}

Alfei L., and Sesti G.: Neuronal increase in the trout (Salmo trutta fario) spinal cord during development. Cell. Mol. Biol. 30, 471-478, 1984.

Alfei L., Bertoncello G., Gelosi E., and Parvopassu F.: A morphometric analysis of the spinal motor pool in relation to its target muscle during growth in the trout, Salmo gairdneri. J. Fish Biol. 34, 65-78, 1989.

Alfei L., Onali A., Spanò L., Colombari P.T., Altavista P.L., and De Vita R.: PCNA/cyclin expression and BrdU uptake define proliferating myosatellite cells during hyperplastic muscle growth of fish (Cyprinus carpio L.). Eur. J. Histochem. 38, 151-162, 1994.

Altmann J.: Are new neurons formed in the brains of adult mammals? Science 135, 1127-1128, 1962.

Altmann J.: Autoradiographic investigation of cell proliferation in the brains of rats and cats. Anat. Rec. 145, 573-591, 1963.

Altmann J.: Autoradiographic and histological studies of postnatal neurogenesis. III. Dating the time of production and onset of differentiation of cerebellar microneurons in rats. J. Comp. Neurol. 136, 269-294, 1969a.

Altmann J.: Autoradiographic and histological studies of postnatal neurogenesis. IV. Cell proliferation and migration in the anterior forebrain, with special reference to persisting neurogenesis in the olfactory bulb. J. Comp. Neurol. 137, 433-458, 1969b.

Altman J., and Das G.D.: Autoradiographic and histological evidence of postnatal hippocampal neurogenesis in rats. J. Comp. Neurol. 124, 319-336,1965.

Baserga R.: Growth regulation of the PCNA gene. J. Cell Sci. 98, 433-436, 1991.

Fig. 2 - Photomicrographs of trout (Oncorhynchus mykiss) spinal cord $10 \mu \mathrm{m}$ microtome cross sections at caudal level stained by H. E. A) In mm 20 long Es, two dividing cells (arrow heads) in mitosis are easily recognizable in the ependymal epithelium surrounding the central canal (cc). Few motoneurones are differentiated in the ventral horn regions (arrow). B) In mm 30 long Es, numerous differentiated principal $(\mathbf{P})$ and secondary $(\mathbf{S})$ motoneurones are seen in the ventral horns. In contrast to the previous stage, many nuclei belonging to glial cell precursors (radial glia, astrocytes and oligodendrocytes) are located in dorsal lateral and ventral positions. Mauthner axons (MA) are observed in the fasciculus longitudinalis medialis. C) In mm 70 fry, the numerous $\mathrm{P}$ and $\mathrm{S}$ motoneurones in the ventral horns and the dorsal horn (dh) neurons are further differentiated. D) In $\mathrm{F}$ of $\mathrm{mm}$ 140, P motoneurones decrease in number for each section but appear of larger size. This same trend is found in $\mathbf{E}$ ) the spinal cord of the mm 260 adult stage in which few large P motoneurones are observed in each section. F) An enlargement of the previous microphotograph shows very large P motoneurones around the central canal. Scale bars: $250 \mu \mathrm{m}$ in A; $500 \mu \mathrm{m}$ in B-F. 

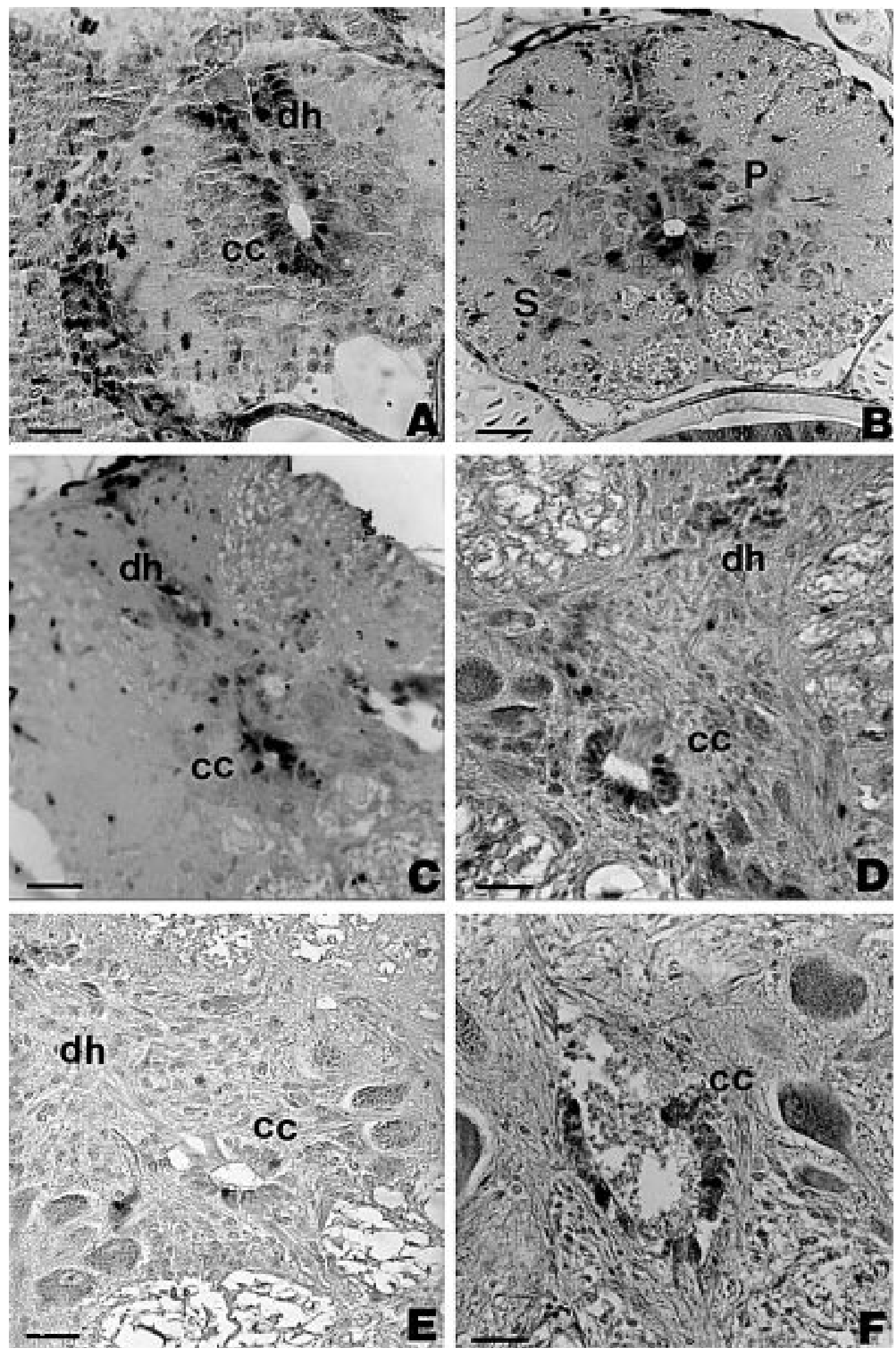
Bayer S.A. , Yackel J.W., and Puri P.S.: Neurons in the rat dentate gyrus granular layer substantially increase during juvenile and adult life. Science 216, 890-892,1982.

Becker T., Wulliman M.F., Becker C.G., Bernhardt R.R., and Schachner M.: Axonal regrowth after spinal cord transection in adult zebrafish. J. Comp. Neurol. 377, 577-595,1997.

Bosch T.J., and Roberts B.L.: The size and number of neurons descending to the spinal cord in relation to body length in the European eel (Anguilla anguilla). Brain Behav. Evol. 44, 5060, 1994.

Bravo R., Fey S.J., Bellatin J., Larsen P.M., Arevaldo J., and Celis J.E.: Identification of a nuclear and of a cytoplasmic polypeptide whose relative portions are sensitive to changes in the rate of cell proliferation. Expl. Cell Res. 136, 311-319, 1981.

Bravo R., and Mcdonald Bravo H.: Existence of two populations of cyclin/proliferating cell nuclear antigen during the cell cycle: association with DNA replication sites. J. Cell Biol. 105, 1549-1554, 1987.

Casasco A., Giordano M., Danova M., Casasco M., Icaro Cornaglia A., and Calligaro A.: PC10 monoclonal antibody to proliferating cell nuclear antigen as probe for cycling cell detection in developing tissues. Histochemistry 99, 191-199, 1993.

Chen J., Chen S., Saha P., Dutta A.: p21 $1^{\text {cipl/wafl }}$ disrupts the recruitment of human Fen1 by proliferating-cell nuclear antigen into the DNA replication complex. Proc. Natl. Acad. Sci. 93, 11597-11602, 1996.

Coggeshall R.E., and Youngblood C.S.: Recovery from spinal transection in fish: regrowth of axons past the transection. Neurosci. Lett. 38, 227-231, 1983.

Corotto F.S. , Henegar J.A., and Maruniak J.A.: Neurogenesis persists in the subependymal layer of the adult mouse brain. Neurosci. Lett. 149, 111-114, 1993.

Fairman M.P.: DNA polymerase /PCNA: actions and interactions. J. Cell Sci. 95, 1-4, 1990

Gould E., Tanapat P., McEwen B.S., Flugge G., and Fuchs E.: Proliferation of granule cell precursors in the dentate gyrus of adult monkeys is diminished by stress. Proc. Natl. Acad. Sci. USA 95, 3168-3171, 1998.

Ino H., and Chiba T.: Expression of proliferating cell nuclear antigen (PCNA) in the adult and developing mouse nervous system. Molecular Brain Res. 78, 163-174, 2000.

Jaskulski D., Deriel J.K., Mercer W.E., Calabretta B., and Baserga R.: Inhibition of cellular proliferation by antisense oligodeoxynucleotides of PCNA cyclin. Science 240, 15441546, 1988.
Johns P.R.: Growth of the adult goldfish eye III. Source of the new retinal cells. J. Comp. Neurol. 176, 343-358, 1977.

Kaplan M.S., and Bell D.H.: Neuronal proliferation in the 9month-old rodent: radioautographic study of granule cells in the hippocampus. Exp. Brain Res. 52, 1-5, 1983.

Koumans J.T.M., and Akster H.A.: Myogenic cells in the development and growth of fish. Comp. Biochem. Physiol. 110 A, 3-20, 1995.

Liu Y.C., Marracino R.L., Keng P.C., Bambara R.A., Lord E.M., Chou W.G., and Zain S.B.: Requirement for proliferating cell nuclear antigen expression during stages of the Chinese hamster ovary cell cycle. Biochemistry 28, 2967-2974, 1989.

Lois C., and Alvarez-Buylla A.: Proliferating subventricular zone cells in the adult mammalian forebrain can differentiate into neurons and glia. Proc. Natl. Acad. Sci. USA 90, 20742077, 1993.

Lois C., and Alvarez-Buylla A.: Long-distance neuronal migration in the adult mammalian brain. Science 264, 11451148, 1994.

Mares V., and Lodin Z.: An autoradiographic study of DNA synthesis in adolescent and adult mouse forebrain. Brain Res. $76,557-561,1974$

Meyer R.L.: Evidence from thymidine labelling for continuing growth of retina and tectum in juvenile goldfish. Exp. Neurol. 59, 99-111, 1978

Meyer R.L., Sakurai K., and Schauwecker E.: Topography of regenerating optic fibers in goldfish traced with local wheat germ injections into retina: evidence for discontinouos microtopography in the retinotectal projection. J. Comp. Neurol. 239, 27-43, 1985

Morris G.F., and Matthews M. B.: Regulation of proliferating cell nuclear antigen during the cell cycle. J. Biol. Chem. 264 , 13856-13864, 1989.

Negishi K., Stell W.K., and Takasaki Y.: Early histogenesis of teleostean retina: studies using a novel immunochemical marker, proliferating cell nuclear antigen (PCNA/cyclin). Dev. Brain Res. 55, 121-125, 1990

Negishi K., Sugawara K., Shinagawa S., Teranishi T., Kuo C$\mathrm{H}$., and Takasaki Y.: Induction of immunoreactive proliferation cell nuclear antigen (PCNA) in goldfish retina following intravitreal injection with tunicamycin. Dev. Brain Res. 63, 71-83, 1991.

Nguyen V., Deschet K., Henrich T., Godet E., Joly J.-S., Wittbrodt J., Chourrout D., and Bourrat F.: Morphogenesis of the

Fig. 3 - Photomicrographs of trout (Oncorhynchus mykiss) spinal cord $8 \mu \mathrm{m}$ microtome cross sections at cervical level, stained by the ABC method using moAb PC10 directed against PCNA. A) Es mm 20 long. PCNA labelled nuclei are located in the ependimal epithelium lining the central canal (cc) and in the dorsal horn ( $\mathbf{d h})$ cells. A few labelled cells are observed in the lateral and ventral funiculi. A similar pattern is observed also in B) $\mathrm{mm} 30$ long Es. C) In $\mathrm{mm} 70$ long fry, a high proliferative rate is observed in the epithelium surrounding the central canal. Few labelled cells are also observed in the $\mathrm{dh}$ and in the lateral and ventral funiculi. In the next stages mm 140 long $\mathrm{F}(\mathbf{D})$, mm 170 long $\mathrm{F}(\mathbf{E})$ and $\mathrm{mm} 260$ long adult (F), only few labelled cells are observed in the central canal and not in each section. Scale bars: $500 \mu \mathrm{m} \mathbf{A}-\mathbf{F}$. 

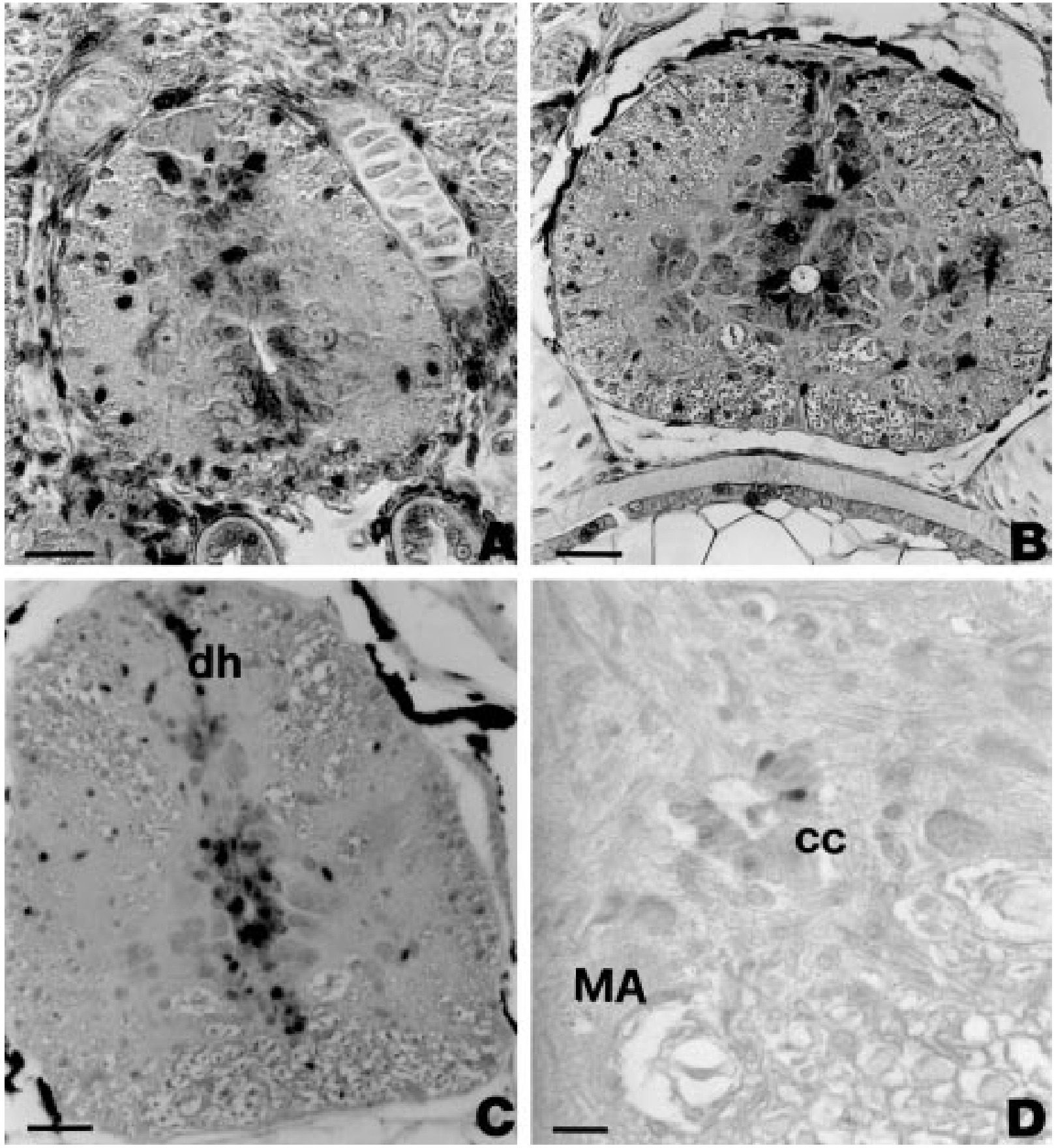

Fig. 4 - Photomicrographs of trout (Oncorhynchus mykiss) spinal cord $8 \mu \mathrm{m}$ microtome cross sections at caudal level, stained by the $\mathrm{ABC}$ method using moAb PC10 directed against PCNA. At this level of the spinal cord, in the $\mathrm{mm} 20$ long Es (A), mm 30 Es $(\mathbf{B}), \mathrm{mm} 60$ fry $(\mathbf{C})$ and $\mathrm{mm} 140 \mathrm{~F}(\mathbf{D})$, the same pattern of PCNA labelling is observed as in the cervical spinal cord level of the same age. $\mathbf{c c}=$ central canal; $\mathbf{d h}=$ dorsal horn; $\mathbf{M A}=$ Mauthner axon. Scale bar: $250 \mu \mathrm{m}$ in $\mathbf{A} ; 500 \mu \mathrm{m} \mathbf{B}-\mathbf{D}$

optic tectum in the Medaka (Oryzias latipes): a morphological and molecular study with special emphasis on cell proliferation. J. Comp. Neurol. 413, 385-404, 1999.
Nieuwenhuys R., Donkelar H. ten, Nicholson C. B.: The central nervous system of vertebrates. Springer, Berlin Heidelberg New York, 1998. 

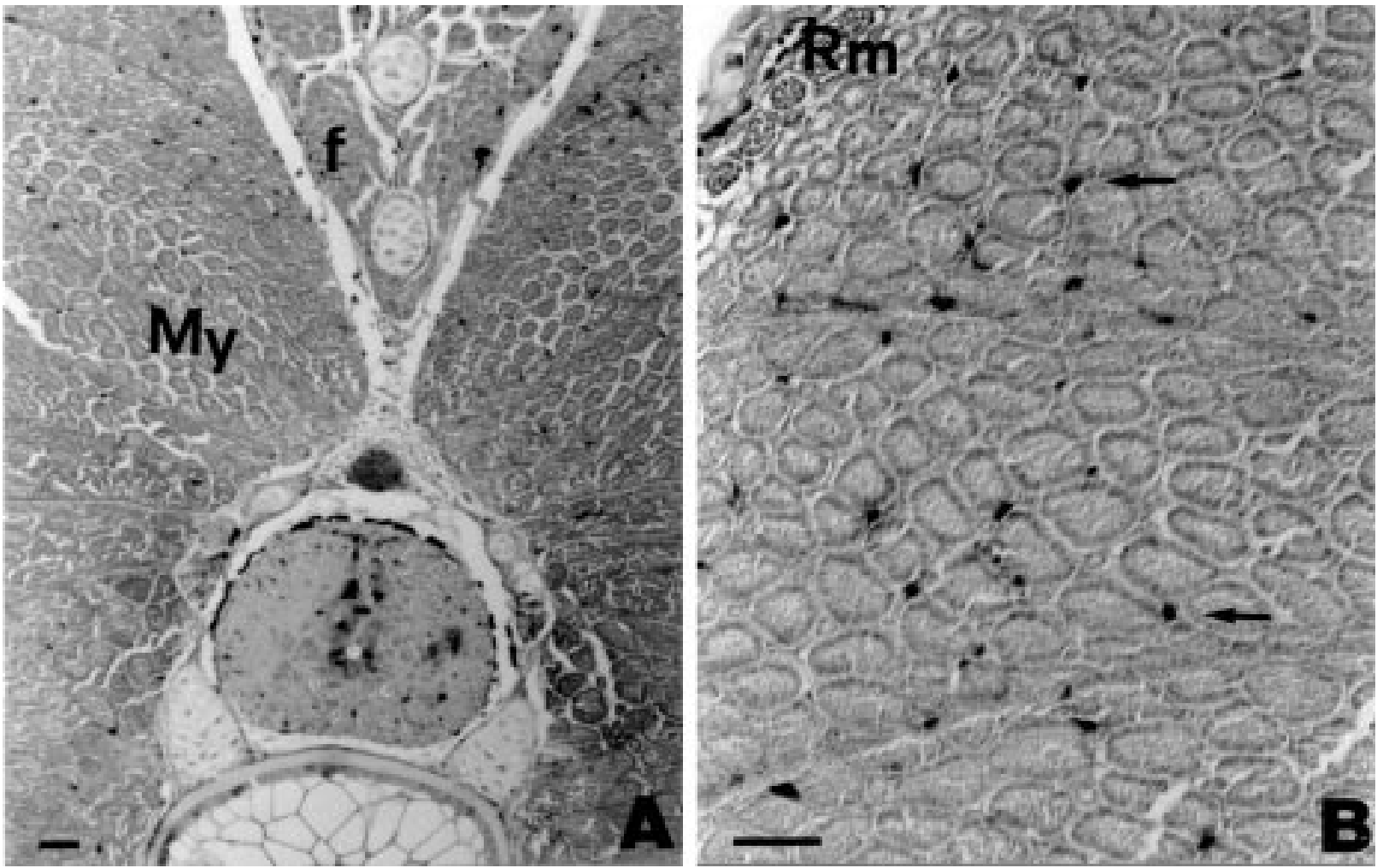

Fig. 5 - Photomicrographs of trout (Oncorhynchus mykiss) $8 \mu \mathrm{m}$ microtome cross sections (mm $30 \mathrm{Es}$ ) at the level of the dorsal fin, stained by the ABC method using moAb PC10 directed against PCNA. A) At this stage, not only many labelled cells are observed In the spinal cord but PCNA positive cells are also found in the myotomal (My) and dorsal fin (f) muscles. B) At larger magnification, many labelled cells in the myotome can be identified as myosatellite cells (arrows). In this section, no labeling is found in the red muscle $(\mathbf{R m})$. Scale bar: $500 \mu \mathrm{m}$.

Northcutt R.G.: The forebrain of gnathostomes: in search of a morphotype. Brain Behav. Evol. 46, 275-319, 1995.

Prasada Rao P.D., Jadhao A.G., and Sharma S.C.: Descending projection neurons to the spinal cord of the goldfish, Carassius auratus. J. Comp. Neurol. 265, 96-108, 1987.

Prasada Rao P.D., Jadhao A.G., and Sharma S.C.: Topographic organization of descending projection neurons to the spinal cord of the goldfish Carassius auratus. Brain Res. 620, 211220, 1993.

Rakic P.: Limits of neurogenesis in primates. Science 227, 1054-1056, 1985.

Sharma S.C., Jadhao A.G., and Prasada Rao P.D.: Regeneration of supraspinal projection neurons in the adult goldfish. Brain Res. 620, 221-228, 1993.

Stickland N.C.: Growth and development of muscle fibres in the rainbow trout (Salmo gairdneri). J. Anat. 137, 323-333, 1983.

Stuermer C.A.O., Bastmeyer M., Bahr M., Strobel G., and Paschke K.: Trying to understand axonal regeneration in the CNS of fish. J. Neurobiol. 23, 537-550, 1992.

Waxman S.G., and Andersonn M.J.: Regeneration of central nervous system structures Apteronotus spinal cord as a mod- el system. In Electroreception (ed. T. H. Bullock and W. Heiligenberg). John Wiley \& Sons, New York, pp. 183-208, 1986.

Waseem N.H., and Lane D.P.: Monoclonal antibody of the proliferating cell nuclear antigen (PCNA): structural conservation and the detection of a nucleolar form. J. Cell Sci. 96, 121-129, 1990.

Weatherley A.H., Gill H.S., and Rogers S.C.: The relationship between mosaic muscle and size in the rainbow trout (Salmo gairdneri). J. Fish Biol. 17, 603-610, 1980.

Weatherley A.H., and Gill H.S.: The biology of fish growth. Academic Press, 1989.

Westerfield M., Mc Murray J.V., and Eisen J.S.: Identified motoneurones and their innervation of axial muscle in the zebrafish. J. Neurosci. 6, 2267-2277, 1986.

Wullimann M.F., Rupp B., and Reichert H.: In: Neuroanatomy of the zebrafish brain: a topological atlas. Birkhauser, Basel, 1996.

Wullimann M.F.: The central nervous system . In: Evans D (ed) The Physiology of fishes. CRC Press, Boca Raton, pp. 245-282, 1997. 
Wullimann M.F., and Puelles L.: Postembryonic neural proliferation in the zebrafish forebrain and its relationship to prosomeric domains. Anat. Embryol. 329, 329-348, 1999.

Yu C.C-W., Woods A.L., and Levison D.A.: The assessmen of cellular proliferation by immunohistochemistry: a review of currently available methods and their applications. Histochem. J. 24, 121-131, 1992.
Zupanc G.K.H., and Horschke I.: Proliferation zones in the brain of adult gymnotiform fish: A quantitative mapping study. J. Comp. Neurol. 353, 213-233, 1995.

Zupanc G.K.H.: Neurogenesis, cell death and regeneration in the adult gymnotiform brain. J. Exp. Biol. 202, 1435-1446, 1999. 